\title{
KARAKTERISTIK BISKUIT (CRACKERS) YANG DIFORTIFIKASI DENGAN KONSENTRASI PENAMBAHAN TEPUNG IKAN PATIN SIAM (Pangasius hypophthalmus) BERBEDA
}

\section{Characteristics Of Crackers (Biskuit) Which Fortified With Catfish (Pangasius hypophthalmus) Fish Flour at Different Concentration}

\author{
Widya Ernisti ${ }^{1}$, Slamet Riyadi², dan Fitra Mulia Jaya² \\ ${ }^{1}$ Alumni Fakultas Perikanan Universitas PGRI Palembang \\ ${ }^{2}$ Staf Pengajar Fakultas Perikanan Universitas PGRI Palembang
}

\begin{abstract}
Abstrak
Biskuit merupakan jenis makanan yang biasa dikonsumsi oleh berbagai kalangan usia. Permasalahan rendahnya kandungan protein dan kalsium biskuit (crackers) diduga dapat diatasi dengan penambahan atau substitusi bahan dasar tepung terigu dengan bahan tepung lain yang kaya protein dan kalsium. Diduga ikan Patin Siam (Pangasius hypophthalmus) yang kaya protein dan kalsium dapat diolah menjadi tepung dan diaplikasikan pada pengolahan produk biskuit (crackers). Penelitian ini bertujuan untuk mengetahui karakteristik fisik biskuit (crackers), mengetahui nilai mutu kimia biskuit (crackers) dan mengetahui nilai mutu organoleptik pada biskuit (crackers). Penelitian ini menggunakan Rancangan Acak Lengkap (RAL) dengan taraf 1 (satu) perlakuan, 5 (lima) perlakuan, masing-masing perlakuan dilakukan 3 (tiga) kali ulangan. Perlakuan pada penelitian ini berupa penambahan tepung ikan Patin Siam (Pangasius hypophthalmus) pada pengolahan biskuit (crackers) dengan berbagai konsentrasi (B/B) yaitu: 0\%, 10\%, 20\%, 30\%, 40\%, (dari berat tepung terigu). Hasil penelitian karakteristik biskuit (crackers) yang difortifikasi dengan konsentrasi penambahan tepung ikan Patin Siam (Pangasius hypophthalmus) yang berbeda. Dapat diperoleh bahwa C2 (10\% Tepung ikan Patin Siam (Pangasius hypopthalmus)) lebih baik dibandingkan dengan konsentrasi penambahan tepung ikan Patin Siam (Pangasius hypothalamus) yang lain.
\end{abstract}

Kata Kunci: Biskuit, Protein, Ikan Patin Siam (Pangasius hypopthalmus)

\begin{abstract}
Crackers are foods that are commonly consumed by all ages. Problems of low protein content and calcium crackers (biskuit) are supposed to be overcome by the addition or substitution of wheat flour with with are rich in protein and calcium, other ingredient which rich in protein and calcium. Catfish (Pangasius Hypopthalmus) with rich in protein and calcium could processed to be flour and applied to processing of crackers (biskuit): in assumption. The objective of the research is to study (1) the physlc characteristics of crackers (biskuit) which fortified with catfish (Pangasius Hypopthalmus) flour. (2) chemical quality values of catfish (Pangasius Hypopthalmus) crackers (biskuit). (3) organoleptic quality. The research used Completely Randomized Design (CRD) with level 1 (One) treatment, each treatment was 3 (three) replications. The treatment in the addition of catfish (Pangasius hypophthalmus) flour in the processing at different concentrations, namely: 0\%, $10 \%, 20 \%, 30 \%, 40 \%$, (of wheat flour weight). The results are C2 (10\% of Patin Fish flour) best treatment in the processing at different concentrations.
\end{abstract}

Keywords: Crackers, Protein, Patin fish (Pangasius hypothalmus) 


\section{PENDAHULUAN}

Crackers merupakan jenis makanan yang biasa dikonsumsi oleh berbagai kalangan usia. Kandungan karbohidrat dan gula sederhana yang cukup tinggi menjadikan biskuit (crackers) biasa dikonsumsi sebagai makanan selingan atau saat sarapan. Meskipun demikian, kandungan protein dari beberapa jenis produk crackers yang beredar di pasaran sangat rendah, yaitu hanya dapat memenuhi $5 \%-8 \%$ AKG protein per takaran saji. Hal ini dapat dipahami karena bahan utama biskuit (crackers) adalah tepung terigu yang berasal dari gandum yang rendah protein dan kalsium.

Permasalahan rendahnya kandungan protein dan kalsium biskuit (crackers) diduga dapat diatasi dengan penambahan atau substitusi bahan dasar tepung terigu dengan bahan tepung lain yang kaya protein. Protein dan kalsium banyak terdapat pada pangan hewani, baik ruminansia, unggas, atau pun ikan air tawar, seperti ikan Patin Siam (Pangasius hypophthalmus).

Ikan Patin Siam (Pangasius hypophthalmus) merupakan salah satu jenis ikan yang saat ini sudah banyak dibudidayakan oleh pembudidaya ikan, akan tetapi pemanfaatannya sebagai produk pangan masih terbatas pada daging. Pengolahan hasil samping ikan (by-products) seperti kepala, tulang belum dimanfaatkan secara optimal.

Menurut Hadiwiyoto (1993), kepala ikan Patin Siam (Pangasius hypophthalmus) memiliki komponen utama berupa protein, lemak, garam, kalsium, dan fosfat. Mempertimbangkan kedua permasalahan di atas, diduga ikan Patin Siam (Pangasius hypophthalmus) yang kaya protein dan kalsium dapat diolah menjadi tepung dan diaplikasikan pada pengolahan produk biskuit (crackers).

\section{METODE PENELITIAN}

Penelitian ini dilaksanakan di Workshop Teknologi Pengolahan Hasil Perikanan (WSTPHP) Fakultas Perikanan Universitas PGRI Palembang dan di Laboratorium Kimia Hasil Pertanian Jurusan Teknologi Pertanian Fakultas Pertanian Universitas Sriwijaya Indralaya. Bahan yang digunakan dalam penelitian ini terdiri dari: tepung ikan Patin (Pangasius hypophthalmus), garam, air, margarin, tepung terigu, gula, ragi, dan bahan kimia yang digunakan untuk analisa proksimat.

Alat yang digunakan dalam penelitian ini terdiri dari alat untuk pengolahan dan alat untuk analisa laboratorium. Alat pengolahan yang digunakan meliputi: alat panci presto, oven, baskom, kompor, pisau, sendok, serok dan timbangan. Alat-alat yang digunakan untuk analisa di laboratorium meliputi: alat titrasi, kain kasa, cawan porselin, desikator, erlenmeyer, gelas beaker, gelas ukur, hot plate, labu kjeldahl, oven, seperangkat alat ekstraksi lemak dan timbangan analitik.

Penelitian ini menggunakan Rancangan Acak Lengkap (RAL) dengan taraf 5 (lima) perlakuan, masing-masing perlakuan dilakukan 3 (tiga) kali ulangan. Perlakuan pada penelitian ini berupa penambahan tepung ikan Patin Siam (Pangasius hypophthalmus) pada pengolahan biskuit (crackers) dengan berbagai konsentrasi (B/B) yaitu: 0\%, 10\%, 20\%, 30\%, 40\% (dari berat tepung terigu).

Proses pengolahan tepung ikan Patin Siam (Pangasius hypophthalmus) dalam penelitian ini dilakukan sesuai dengan prosedur Hadiwiyoto (1993), yang dimodifikasi pada bahan baku. Prosedur pembuatan tepung ikan Patin Siam (Pangasius hypophthalmus) adalah sebagai berikut:

(1) Ikan Patin Siam (Pangasius hypophthalmus) dicuci dan dibuang isi perut dan insangnya (2) Ikan Patin Siam (Pangasius hypophthalmus) yang sudah bersih kemudian dikukus selama 30 menit yang bertujuan untuk mempermudah proses selanjutnya. (3) Ikan Patin Siam (Pangasius hypophthalmus) dioven selama 4 jam pada suhu $160^{\circ} \mathrm{C}$. (4) Setelah dioven, ikan Patin Siam (Pangasius hypophthalmus) diblender dan didinginkan.

Bahan-bahan yang digunakan dalam proses pembuatan biskuit (crackers) ikan Patin Siam (Pangasius hypophthalmus) meliputi: tepung terigu, garam, air, margarin, ragi, gula, dan tepung ikan Patin Siam (Pangasius hypophthalmus). Komposisi adonan pengolahan biskuit (crackers) dengan penambahan tepung ikan Patin Siam (Pangasius hypophthalmus)

Adapun cara proses pengolahan biscuit (crackers) ikan Patin Siam (Pangasius hypophthalmus) adalah sebagai berikut:

(1) Tepung terigu 150 gram dicampur dengan garam $3 \%(\mathrm{~B} / \mathrm{B})$, gula $5 \%(\mathrm{~B} / \mathrm{B})$, ragi $2 \%$ (B/B), air 5\% (B/B), margarin 5\% (B/B) dan tepung ikan Patin Siam (Pangasius hypophthalmus) dengan berbagai konsentrasi (B/B) $(0 \%, 10 \%, 20 \%, 30 \%, 40$ $\%)$ diaduk hingga rata.

(2) Pengadonan dilanjutkan dengan penambahan sisa tepung terigu 50 gram sedikit demi sedikit sampai tercampur rata.

(3) Setelah adonan biskuit (crackers) tercampur 
rata, didiamkan selama 30 menit.

(4) Adonan yang sudah difermentasi, kemudian dicetak dengan menggunakan pasta machine, dengan tebal $3 \mathrm{~mm}$, panjang $5 \mathrm{~cm}$, dan lebar $3 \mathrm{~cm}$.

(5) Adonan dioven dengan suhu $160^{\circ} \mathrm{C}$ selama 20 menit.

(6) Biskuit (crackers) didinginkan di suhu ruang.

(7) Pengemasan.

Parameter yang diamati pada penelitian meliputi: uji organoleptik, analisis fisik (Rendemen, Warna, Tekstur dan Kerenyahan), analisis kimia (kadar protein, abu, lemak, karbohidrat, air).

\section{Uji Organoleptik}

Uji organopletik yang dilakukan dalam penelitian ini adalah uji kesukaan (hedonik) terhadap biscuit (crackers). Parameter penilaian organoleptik meliputi: rendemen, penampakan, warna, aroma, tekstur dan rasa dilakukan terhadap biskuit (crackers). Pengujian organoleptik berdasaarkan uji kesukaan hedonik berskala 1-5 (Rahayu, 2001). Skor penilaian uji hedonik digunakan adalah skor 5 (sangat suka), 4 (suka), 3 (netral), 2 (tidak suka), 1 (sangat tidak suka). Panelis yang memberikan penilaian adalah panelis agak terlatih dan jumlahnya 25 orang, pengkodean untuk contoh menggunakan tiga angka yang bersifat acak. Prosedur penyiapan sampel dari uji hedonik adalah sebagai berikut:

(1) Masing-masing biscuit (crackers) diletakkan dalam piring kecil sebanyak 1sampel untuk setiap perlakuan. (2) Panelis diminta untuk menentukan nilai organoleptik berupa penampakan, warna, aroma, dan kerenyahan biskuit (crackers).

\section{Analisis Fisik}

\section{a. Pengukuran Rendemen (AOAC, 2005)}

Rendemen merupakan hasil akhir yang dihitung berdasarkan proses input dan output. Rendemen dihitung berdasarkan berat basah. Cara mengukur rendemen adalah sebagai berikut:

$$
\text { Rendemen }=\frac{A}{B} x 100 \%
$$

Keterangan: $\mathrm{A}=$ berat akhir

$\mathrm{B}=$ berat awal

\section{b. Warna}

Mutu bahan pangan pada umumnya tergantung pada beberapa faktor. Faktor-faktor tersebut antara lain cita rasa, tekstur, nilai gizi, mikrobiologis, dan warna. Sebelum faktor yang lain dipertimbangkan, secara visual faktor warna akan tampil lebih dulu (Winarno, 1997). Perubahan warna biskuit (crackers) diukur dengan menggunakan alat color checker.

\section{c. Tekstur}

Analisa tekstur dilakukan terhadap biskuit (crackers) dengan konsentrasi yang berbeda dengan alat texture analyzer merk Brookfier (Fardiah, 2006).

\section{d. Kerenyahan}

Kekerasan/kerenyahan diukur dengan menggunakan penetrometer.

\section{Analisis Kimia}

a. Analisis Kadar Protein Metode Mikro Kjeldalhl (AOAC, 2005)

Penentuan kadar protein dilakukan dengan Metode Total Nitrogen yang didasarkan pada reaksi penetralan asam basah. Kadar protein dihitung berdasarkan kesetimbangan reaksi kimia. Tahap-tahap yang dilakukan dalam analisis protein terdiri dari tiga tahap, yaitu destruksi, destilasi, dan titrasi.

\section{b. Analisis Kadar Lemak Metode Soxhlet (AOAC, 2005)}

Prinsip analisis kadar lemak diawali dengan melakukan pengekstrakan sampel dengan pelarut organik untuk mengeluarkan lemak dengan bantuan pemanasan pada suhu titik didih pelarut selama 8 jam. Pelarut organik yang mengikat lemak selanjutnya dipisahkan dengan proses penguapan (evaporasi), sehingga hasil lemak tertinggal dalam labu. Penetapan bobot lemak dihitung secara gravimetrik.

\section{c. Analisis kadar karbohidrat by difference (Winarno, 1997)}

Perhitungan kadar karbohidrat dilakukan menggunakan metode by difference yaitu pengurangan $100 \%$ dengan jumlah dari hasil empat komponen yaitu kadar air, protein, lemak dan abu.

\section{d. Analisis Kadar Air Metode Oven (AOAC, 2005)} berikut:

Prosedur analisis kadar air adalah sebagai

(1) Keringkan cawan porselen dalam oven pada suhu 102 - $105{ }^{\circ} \mathrm{C}$ selama 30 menit. (2) Dinginkan cawan tersebut dalam desikator (kurang lebih 30 menit) (3) Kemudian timbang 
berat cawan (A). (4) Sampel ditimbang sebanyak 1 - 2 g (B), kemudian dimasukan kedalam cawan. (5) Masukkan cawan yang berisi sampel tersebut ke dalam oven dengan suhu $102-105^{\circ} \mathrm{C}$ selama 6 jam. (6) Cawan tersebut kemudian didinginkan dalam desikator dan ditimbang bobotnya dan diukur kadar airnya.

\section{Analisis Statistik}

\section{a. Analisis Statistik Parametrik}

Analisis statistik parametrik dilakukan untuk menganalisis data dari hasil analisa fisik meliputi: rendemen, warna, tekstur dan kerenyahan, dan analisa kimia meliputi: kadar air, abu, protein, lemak dan karbohidrat.

\section{b. Analisis Statistik Non Parametrik}

Data uji sensoris dengan uji hedonik dianalisa dengan menggunakan uji model Friedman - Connever.

Menurut Connover dalam karya Imam dan Davenport (1980), yang dikutip oleh Sudjono (1985), menyatakan bahwa langkah pertama adalah dengan memberi pangkat pada masingmasing angka hasil percobaan. Pangkat diberikan pada masing-masing baris panelis. Banyaknya perlakuan dibandingkan dengan masing-masing skor, skor tertinggi diberi pangkat 1. Apabila terdapat dua atau tiga pangkat yang sama maka dibuat rerata.

\section{HASIL PEMBAHASAN}

\section{A. Analisis Fisik}

\section{Tekstur}

Pengukuran tekstur biskuit (crackers) ikan Patin Siam (Pangasius hypophthalmus) menggunakan alat texture analyser, dan dalam menggunakan alat ini memberikan pengaruh gaya terhadap produk. Adapun hasil pengukuran rata-rata tekstur biskuit (crackers) ikan Patin Siam (Pangasius hypophthalmus) dapat dilihat pada Gambar 1.

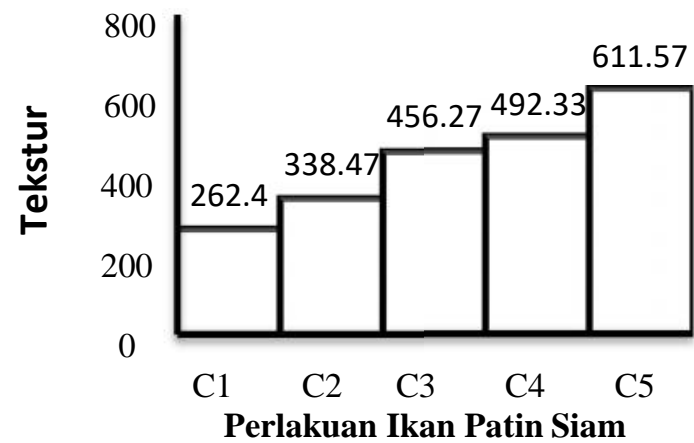

Gambar 1. Rata-rata nilai tekstur biskuit (crackers) ikan Patin Siam (Pangasius hypophthalmus)

Hasil uji analisis keragaman menyatakan bahwa konsentrasi perlakuan penambahan tepung ikan Patin Siam (Pangasius hypophthalmus) yang berbeda pada biskuit (crackers) berbeda nyata terhadap tekstur yang dihasilkan. Oleh karena itu, dilakukan uji lanjut analisis keragaman. Nilai rata-rata tekstur menunjukkan nilai tertinggi terdapat pada perlakuan C5 (40\% tepung ikan patin siam) dengan nilai rata-rata $611,57 \%$, sedangkan nilai rata-rata tekstur terendah terdapat pada perlakuan $\mathrm{C} 1$ (0\% tepung ikan patin siam) dengan nilai rata-rata $262,40 \%$. Hasil analisis keragaman menunjukkan bahwa konsentrasi perlakuan penambahan tepung ikan Patin Siam (Pangasius hypophthalmus) yang berbeda pada perlakuan berbeda nyata terhadap nilai rata- rata tekstur biskuit (crackers) ikan Patin Siam (Pangasius hypophthalmus) pada taraf uji 5\%. Pada tabel 9, Menunjukkan bahwa perlakuan C5 (40\% Tepung ikan Patin Siam) berbeda tidak nyata dengan C4 (30\% Tepung ikan Patin Siam) Tepung ikan Patin Siam) berbeda nyata dengan perlakuan $\mathrm{C} 2$, dan $\mathrm{C} 1$. Nilai rata-rata tekstur menunjukkan terdapat pada perlakuan C5 nilai tertinggi (40\% Tepung ikan Patin Siam) dengan nilai rata-rata 611,57\% dengan kriteriakeras, sedangkan nilai rata-rata tekstur terendah terdapat pada perlakuan $\mathrm{C} 1$ (0\% Tepung ikan Patin Siam) dengan nilai rata-rata $102,13 \%$ dengan kriteria lembut sedangkan nilai rata - rata yang terbaik untuk biskuit (crackers) terdapat pada C2 (10\% Tepung ikan Patin Siam) 262,40\% dan C3 (20\% Tepung ikan Patin Siam) 291,10\%.

Pada nilai rata-rata tekstur biskuit (crackers) cenderung mengalami peningkatan dengan semakin tingginya tepung ikan Patin Siam yang ditambahkan. Hal ini disebabkan tekstur biskuit (crackers) ikan Patin Siam (Pangasius hypophthalmus) yang dihasilkan keras. Hal ini disebabkan tekstur biskuit (crackers) ikan Patin Siam (Pangasius hypophthalmus) yang dihasilkan keras. Hal ini dapat terjadi karena pada tepung ikan Patin Siam (Pangasius hypophthalmus) tidak mengandung gluten yang merupakan komponen sangat penting dalam proses adonan yang akan mempengaruhi tekstur biskuit (Manley, 2000) dan menurut Sudarmaji, et al (1989) menyatakan bahwa makanan yang berasal dari hewani mengandung kandungan beberapa mineral seperti kalsium, besi, dan fosfor yang terdapat pada hewan tersebut.

\section{Warna}

Pengukuran warna dilakukan dengan menggunakan alat colour reader CR-10. Alat ini dapat membedakan warna biskuit (crackers) ikan 
Patin Siam (Pangasius hypophthalmus) berdasarkan tiga nilai yaitu: lightness (L), chroma $(\mathrm{C})$, dan hue $(\mathrm{H})$.

\section{a. Lightness (L)}

Nilai lightness merupakan tingkat warna berdasarkan pencampuran dengan unsur warna putih sebagai unsur warna yang memunculkan kesan warna terang dan gelap.

Nilai koreksi warna lightness berkisar antara 0 untuk warna paling gelap (hitam) dan 100 untuk warna paling terang (putih). Adapun hasil pengukuran nilai rata - rata warna lightness biskuit (crackers) ikan Patin Siam (Pangasius hypophthalmus) dapat dilihat pada Gambar 2.

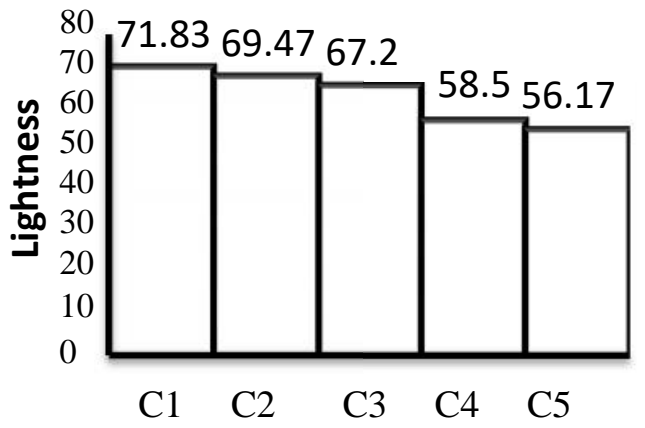

Perlakuan Tepung Ikan Patin Siam

Gambar 2. Rata-rata warna lightness biskuit (crackers) ikan Patin Siam (Pangasius hypophthalmus)

Hasil uji analisis keragaman menyatakan bahwa konsentrasi perlakuan penambahan tepung ikan Patin Siam (Pangasius

hypophthalmus) yang berbeda pada biskuit (crackers) berbeda sangat nyata terhadap warna yang dihasilkan. Oleh karena itu, dilakukan uji lanjut analisis keragaman. Hasil uji lanjut BNT, pengaruh konsentrasi penambahan tepung ikan Patin Siam (Pangasius hypophthalmus) yang berbeda warna lightness (L) biskuit (crackers) ikan Patin Siam (Pangasius hypophthalmus). Nilai rata-rata warna lightness menunjukkan nilai tertinggi terdapat pada perlakuan $\mathrm{C} 1 \quad(0 \%$ Tepung ikan Patin perlakuan C1 (0\% Tepung ikan Patin perlakuan C1 (0\% Tepung ikan Patin terendah terdapat pada perlakuan C5 $(40 \%$ Tepung ikan Patin Siam) dengan nilai rata-rata $56,17 \%$. Hasil analisis keragaman menunjukkan bahwa konsentrasi perlakuan penambahan tepung ikan Patin Siam (Pangasius hypophthalmus) yang berbeda pada perlakuan berbeda sangat nyata terhadap nilai rata-rata warna lightness biskuit (crackers) ikan Patin Siam (Pangasius hypophthalmus) pada taraf uji $5 \%$.

Nilai rata-rata warna lightness cenderung mengalami penurunan dengan semakin tingginya tepung ikan Patin Siam yang ditambahkan, perubahan warna lightness tersebut dipengaruhi oleh reaksi mailard. Reaksi mailard adalah reaksi antarkarbohidrat, khususnya gula pereduksi dengan amino primer yang menghasilkan senyawa berwarna coklat yang disebut melanoidin (Winarno, 1997).

\section{b. Chroma}

Chroma merupakan besaran yang digunakan dalam komponen warna, yang menunjukkan intensitas warna (Winarno, 1991). Nilai rata - rata chroma biskuit (crackers) ikan Patin Siam (Pangasius hypophthalmus) dapat dilihat pada Gambar 3.

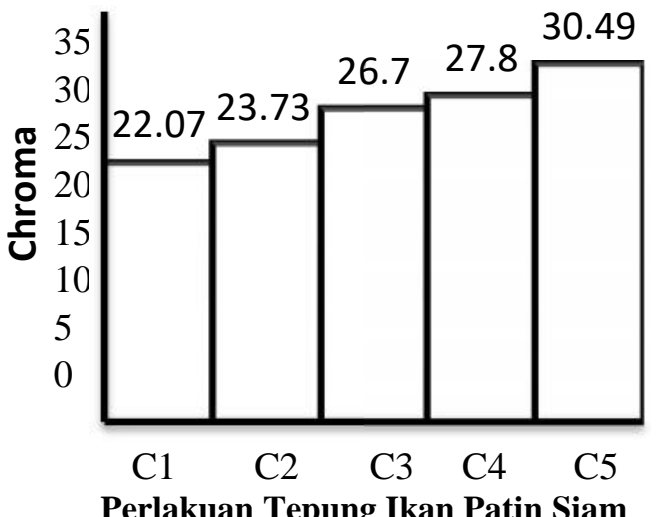

Gambar 3. Rata-rata warna lightness biskuit (crackers) ikan Patin Siam (Pangasius hypophthalmus)

Hasil uji analisis keragaman menyatakan bahwa konsentrasi perlakuan penambahan tepung ikan Patin Siam (Pangasius hypophthalmus) yang berbeda pada biskuit (crackers) berbeda sangat nyata terhadap warna yang dihasilkan. Oleh karena itu, dilakukan uji lanjut analisis keragaman. Hasil uji lanjut BNT pengaruh konsentrasi perlakuan penambahan tepung ikan Patin Siam (Pangasius hypophthalmus) yang berbeda. Warna chroma (C) biskuit (crackers) ikan Patin Siam (Pangasius hypophthalmus).

Nilai rata-rata warna chroma menunjukkan nilai tertinggi terdapat pada perlakuan C5 (40\% tepung ikan Patin Siam) dengan nilai rata-rata warna chroma terendah terdapat pada perlakuan $\mathrm{C} 1 \quad(0 \%$ tepung ikan Patin Siam) dengan nilai rata-rata 30,49\%. Hasil analisis keragaman menunjukkan bahwa konsentrasi perlakuan penambahan tepung ikan Patin Siam (Pangasius hypophthalmus) yang berbeda pada perlakuan berbeda sangat nyata terhadap nilai rata-rata warna chroma biskuit (crackers) ikan Patin Siam (Pangasius hypophthalmus) pada taraf uji $5 \%$. 
Nilai rata-rata warna chroma cenderung mengalami penurunan dengan semakin tingginya tepung ikan Patin Siam yang ditambahkan, perubahan warna chroma tersebut dipengaruhi oleh reaksi mailard. Reaksi mailard adalah reaksi antar karbohidrat, khususnya gula pereduksi dengan amino primer yang menghasilkan senyawa berwarna coklat yang disebut melanoidin (Winarno, 1997).

\section{c. Hue}

Nilai hue merupakan nilai yang mewakili panjang gelombang yang dominan yang akan menentukan apakah warna tersebut merah, hijau, atau kuning (Winarno, 1991).

Adapun hasil pengukuran nilai rata-rata hue biskuit (crackers) ikan Patin Siam (Pangasius hypophthalmus) dapat dilihat pada Gambar 4.

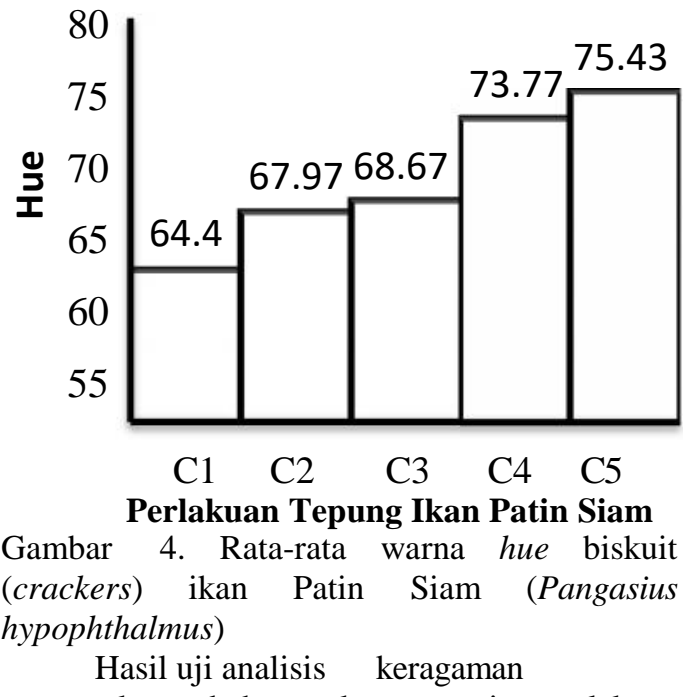
menyatakan bahwa konsentrasi perlakuan penambahan tepung ikan Patin Siam (Pangasius hypophthalmus) yang berbeda pada biskuit (crackers) berbeda sangat nyata terhadap warna yang dihasilkan. Oleh karena itu, dilakukan uji lanjut analisis keragaman.

Nilai rata-rata warna hue menunjukkan nilai tertinggi terdapat pada perlakuan C5 (40\% tepung ikan Patin Siam) dengan nilai rata-rata $75,43 \%$, sedangkan nilai rata-rata warna hue terendah terdapat pada perlakuan $\mathrm{C} 1(0 \%$ tepung ikan Patin Siam) dengan nilai rata-rata $64,40 \%$. Hasil analisis keragaman menunjukkan bahwa konsentrasi perlakuan penambahan tepung ikan Patin Siam (Pangasius hypophthalmus) yang berbeda pada perlakuan berbeda sangat nyata terhadap nilai rata-rata warna hue biskuit (crackers) ikan Patin Siam (Pangasius hypophthalmus) pada taraf uji $5 \%$.

Nilai rata - rata warna hue cenderung mengalami peningkatan dengan semakin tingginya tepung ikan Patin Siam yang ditambahkan. Perubahan warna hue tersebut dipengaruhi oleh reaksi mailard pada saat pengeringan dalam oven (Raikos $d k k$., 2006; Jing $d k k ., 2009)$.

\section{B. Analisis Kimia \\ 1. Kadar Air}

Nilai rata-rata kadar air biskuit (crackers) ikan Patin Siam (Pangasius hypophthalmus) menunjukkan kadar air tertinggi terdapat pada perlakuan C5 (40\% Tepung ikan Patin Siam) dengan nilai rata-rata $5,95 \%$, sedangkan nilai kadar air terendah terdapat pada perlakuan $\mathrm{C} 1$ (0\% Tepung ikan Patin Siam) dengan nilai ratarata $5,06 \%$. Hal ini dapat dilihat pada Gambar 5.

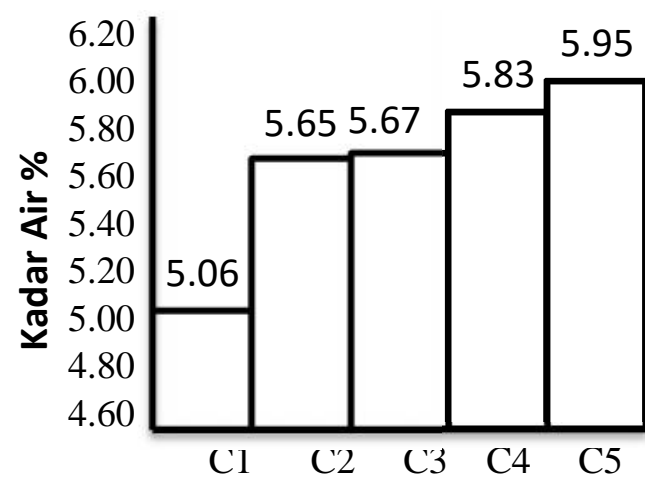

Perlakuan Tepung Ikan Patin Siam

Gambar 5. Rata-rata kadar air biskuit (crackers) ikan Patin Siam (Pangasius hypophthalmus)

Kadar air biskuit (crackers) cenderung meningkat dengan semakin tingginya tepung ikan Patin Siam yang ditambahkan. Hasil analisis keragaman menunjukkan bahwa konsentrasi perlakuan penambahan tepung ikan Patin Siam (Pangasius hypophthalmus) yang berbeda pada perlakuan tidak berbeda nyata terhadap nilai kadar air biskuit (crackers) tepung ikan Patin Siam (Pangasius hypophthalmus) pada taraf uji $5 \%$.

\section{Kadar Abu}

Abu merupakan residu dari hasil pembakaran bahan organik pada suhu tinggi. Kadar abu dapat digunakan sebagai indikator mutu pangan. Nilai rata-rata kadar abu biskuit (crackers) ikan Patin Siam (Pangasius hypophthalmus) menunjukkan kadar abu tertinggi terdapat pada perlakuan C5 (40\% Tepung ikan Patin Siam) dengan nilai rata-rata $5,63 \%$, sedangkan nilai kadar abu terendah terdapat pada perlakuan $\mathrm{C} 1$ (0\% Tepung ikan Patin Siam) dengan nilai rata-rata $2,73 \%$. Hal ini dapat dilihat pada Gambar 6. 


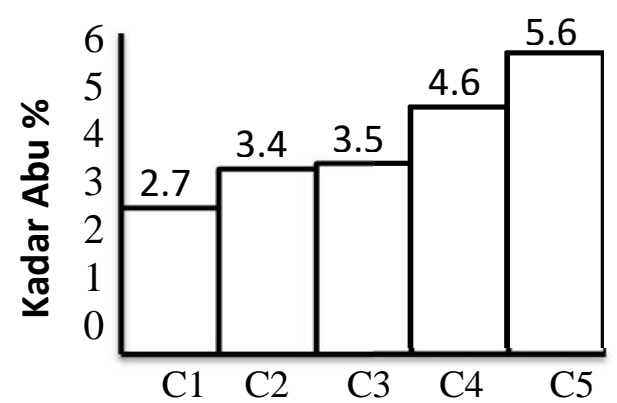

Perlakuan Tepung Ikan Patin Siam

Gambar 6. Rata-rata kadar abu biskuit (crackers) ikan Patin Siam (Pangasius hypophthalmus)

Hasil analisis keragaman menunjukkan bahwa konsentrasi perlakuan penambahan tepung ikan Patin Siam (Pangasius hypophthalmus) yang berbeda berbeda sangat nyata terhadap nilai kadar abu biskuit (crackers) ikan Patin Siam (Pangasius hypophthalmus).

Kadar abu biskuit (crackers) cenderung meningkat dengan semakin tingginya tepung ikan Patin Siam yang ditambahkan. Menurut Sudarmaji, et al (1989) menyatakan bahwa makanan yang berasal dari hewani mengandung kadar abu yang tinggi, hal ini disebabkan oleh kandungan beberapa mineral seperti kalsium, besi dan fosfor yang terdapat pada hewan tersebut, maka semakin tinggi tepung ikan yang ditambahkan maka kadar abu yang dihasilkan akan semakin tinggi.

\section{Kadar Protein}

Nilai rata-rata kadar protein biskuit (crackers) ikan Patin Siam (Pangasius hypophthalmus) menunjukkan kadar protein tertinggi terdapat pada perlakuan C5 (40\% Tepung ikan Patin Siam) dengan nilai rata -rata $34,28 \%$, sedangkan nilai kadar protein terendah terdapat pada perlakuan $\mathrm{C} 1$ (0\% Tepung ikan Patin Siam) dengan nilai rata -rata $27,25 \%$. Hal ini dapat dilihat pada Gambar 7.

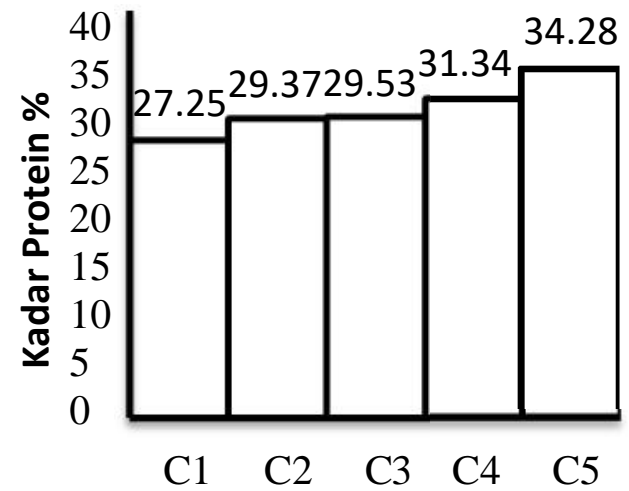

Perlakuan Tepung Ikan Patin Siam

Gambar 7. Rata-rata kadar protein biskuit (crackers) ikan Patin Siam (Pangasius

\section{hypophthalmus)}

Kadar protein biskuit (crackers) cenderung meningkat dengan semakin tingginya tepung ikan Patin Siam yang ditambahkan, hal ini karena ikan Patin Siam mengandung protein, sehingga semakin tinggi tepung ikan yang ditambahkan menyebabkan kadar protein biskuit (crackers) menjadi semakin meningkat. Dari penelitian pendahuluan yang dilakukan pada uji kadar protein pada tepung ikan adalah 20,13\%. Hasil analisis keragaman menunjukkan bahwa konsentrasi perlakuan penambahan tepung ikan Patin Siam (Pangasius hypophthalmus) yang berbeda pada perlakuan tidak berbeda nyata terhadap nilai kadar protein biskuit (crackers) ikan Patin Siam (Pangasius hypophthalmus) pada taraf uji $5 \%$.

\section{Kadar Lemak}

Nilai rata - rata kadar lemak biskuit (crackers) ikan Patin Siam (Pangasius hypophthalmus) menunjukkan kadar lemak tertinggi terdapat pada perlakuan C5 (40\% Tepung ikan Patin Siam) dengan nilai rata- rata $29,68 \%$, sedangkan nilai kadar lemak terendah terdapat pada perlakuan C1 (0\% Tepung ikan Patin Siam) dengan nilai rata-rata $23,05 \%$. Hal ini dapat dilihat pada Gambar 8.

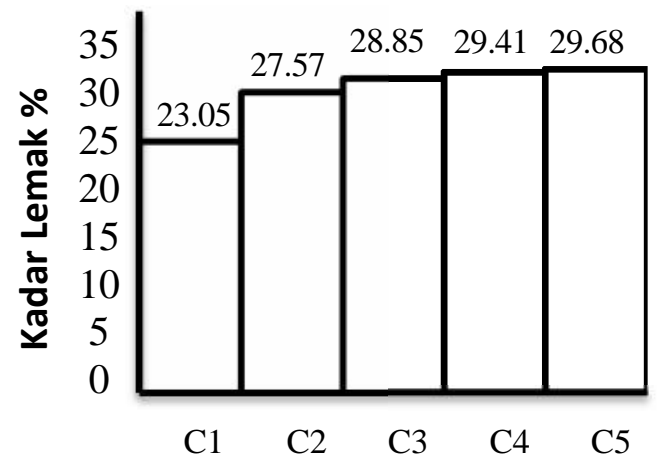

Perlakuan Tepung Ikan Patin Siam

Gambar 8. Rata-rata kadar lemak biskuit (crackers) ikan Patin Siam (Pangasius hypophthalmus).

Hasil analisis keragaman menunjukkan bahwa konsentrasi perlakuan penambahan tepung ikan Patin Siam (Pangasius hypophthalmus) yang berbeda berbeda nyata terhadap nilai kadar lemak biskuit (crackers) ikan Patin Siam (Pangasius hypophthalmus). Kadar lemak biskuit (crackers) cenderung meningkat dengan semakin tingginya tepung ikan Patin Siam yang ditambahkan. maka semakin tinggi nilai kadar lemak yang dihasilkan. Karena ikan Patin Siam (Pangasius hypopthalmus) adalah ikan yang banyak mengandung lemak. Dari penelitian pendahuluan 
yang dilakukan hasil uji kadar lemak pada tepung ikan Patin Siam yang menjadi bahan baku pembuatan biskuit (crackers) adalah $30,12 \%$.

\section{Kadar Karbohidrat}

Nilai rata-rata kadar karbohidrat biskuit (crackers) ikan Patin Siam (Pangasius hypophthalmus) menunjukkan kadar karbohidrat tertinggi terdapat pada perlakuan C1 (40\% Tepung ikan Patin Siam) dengan nilai rata-rata $34,97 \%$, sedangkan nilai kadar karbohidrat terendah terdapat pada perlakuan C5 $(0 \%$ Tepung ikan Patin Siam) dengan nilai rata -rata $24,48 \%$. Hal ini dapat dilihat pada Gambar 9.

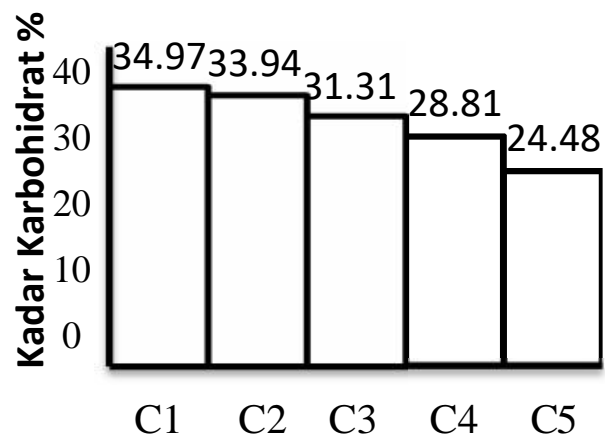

Perlakuan Tepung Ikan Patin Siam

Gambar 9. Rata-rata kadar karbohidrat biskuit (crackers) ikan Patin Siam (Pangasius hypophthalmus)

Kadar karbohidrat biskuit (crackers) cenderung menurun dengan semakin tingginya tepung ikan Patin Siam yang ditambahkan. Hal ini disebabkan karena produk perikanan tidak mengandung serat, umumnya karbohidrat tersebut dalam bentuk glikogen (Nurjanah et al.2009).

Hasil analisis keragaman menunjukkan bahwa konsentrasi perlakuan penambahan tepung ikan Patin Siam (Pangasius hypophthalmus) yang berbeda pada perlakuan tidak berbeda nyata terhadap nilai kadar karbohidrat biskuit (crackers) ikan Patin Siam (Pangasius hypophthalmus) pada taraf uji 5\%.

\section{Uji Hedonik}

\section{Penampakan}

Nilai rata-rata penampakan biskuit (crackers) ikan Patin Siam (Pangasius hypophthalmus) dapat dilihat pada Gambar 10.

Hasil uji Friedman Conover menyatakan bahwa konsentrasi perlakuan penambahan tepung ikan Patin Siam (Pangasius hypophthalmus) yang berbeda pada biskuit (crackers) tidak berbeda nyata terhadap penampakan yang dihasilkan. Oleh karena itu, tidak dilakukan uji lanjut Friedman Conover.

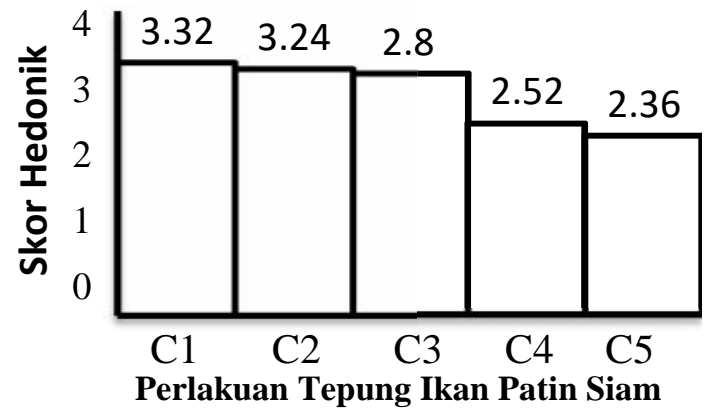

Gambar 10. Rata - rata skala hedonik penampakan biskuit (crackers) ikan Patin Siam (Pangasius hypophthalmus)

Berdasarkan uji hedonik, menunjukkan bahwa konsentrasi perlakuan penambahan tepung ikan Patin Siam yang berbeda pada biskuit (crackers) tidak berbeda nyata terhadap penampilan yang dihasilkan. Diketahui bahwa tingkat penerimaan panelis terhadap penampakan biskuit (crackers) ikan Patin Siam (Pangasius hypophthalmus) menghasilkan ratarata nilai penampakan biskuit (crackers) ikan Patin Siam (Pangasius hypophthalmus) berkisar antara 2,36 sampai 3,32. Tingkat kesukaan nilai tertinggi terdapat pada perlakuan C1 (0\% Tepung ikan Patin Siam) dan terendah terdapat pada perlakuan C5 (40\% Tepung ikan Patin Siam). Proses pembuatan biskuit (crackers) dengan tingkat penambahan tepung ikan Patin Siam yang semakin besar, menyebabkan adonan lebih susah dicetak sehingga menghasilkan biskuit (crackers) yang kurang rapi. Menurut Matz dan Matz (1978), kriteria mutu sensoris biskuit (crackers) untuk penampakan yaitu, biskuit (crackers) sebaiknya berbentuk persegi empat, halus, dan lembut.

\section{Warna}

Nilai rata - rata warna biskuit (crackers) ikan Patin Siam (Pangasius hypophthalmus) dapat dilihat pada Gambar 11.

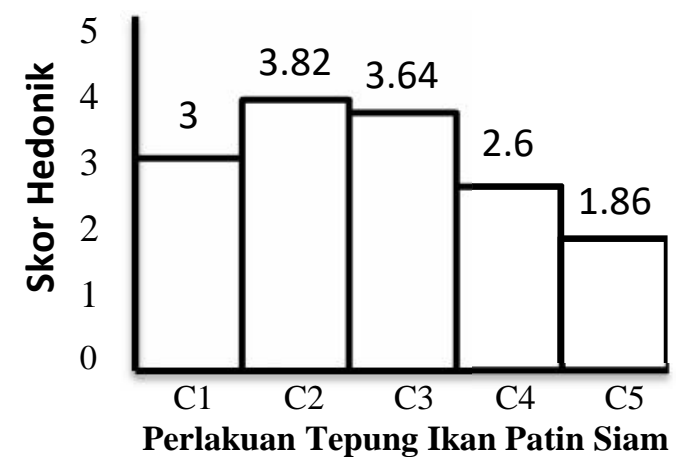

Gambar 11. Rata - rata skala hedonik warna biskuit (crackers) ikan Patin Siam (Pangasius hypophthalmus)

Hasil uji Friedman Conover 
menyatakan bahwa konsentrasi perlakuan penambahan tepung ikan Patin Siam (Pangasius hypophthalmus) yang berbeda pada biskuit (crackers) berbeda nyata terhadap warna yang dihasilkan. Oleh karena itu, dilakukan uji lanjut Friedman Conover. Berdasarkan uji hedonik, diketahui bahwa tingkat penerimaan panelis terhadap warna biskuit (crackers) ikan Patin Siam (Pangasius hypophthalmus) menghasilkan rata-rata nilai warna biskuit (crackers) ikan Patin Siam (Pangasius hypophthalmus) berkisar antara 1,86 sampai 3,82. Tingkat kesukaan nilai tertinggi terdapat pada perlakuan C2 (10\% Tepung ikan Patin Siam) dan nilai terendah terdapat pada perlakuan C5 (40\% Tepung ikan Patin Siam). Hal ini karena panelis menyukai warna biskuit (crackers) yang agak kecoklatan, yaitu C2 (10\% Tepung ikan Patin Siam) dan tidak menyukai warna yang pucat dan coklat gelap/kecoklatan. Warna kecoklatan dipengaruhi oleh reaksi mailard. Reaksi mailard adalah reaksi antar karbohidrat, khususnya gula pereduksi dengan amino primer yang menghasilkan senyawa bewarna coklat yang disebut melanoidin (Winarno, 1997). Panelis lebih menyukai biskuit dengan warna yang lebih cerah daripada biskuit dengan warna yang gelap (Winarno, 1997).

\section{Tekstur}

Nilai rata - rata tekstur biskuit (crackers) ikan Patin Siam (Pangasius hypophthalmus) dapat dilihat pada Gambar 12.

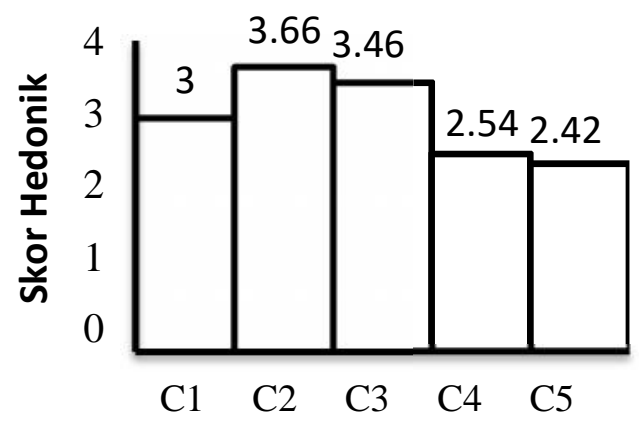

Perlakuan Tepung Ikan Patin Siam

Gambar 12. Rata-rata skala hedonik tekstur biskuit (crackers) ikan Patin Siam (Pangasius hypophthalmus).

Hasil uji Friedman Conover menyatakan bahwa konsentrasi perlakuan penambahan tepung ikan Patin Siam (Pangasius hypophthalmus) yang berbeda pada biskuit (crackers) berbeda nyata terhadap tekstur yang dihasilkan oleh karena itu dilakukan uji lanjut Friedman Conover. Berdasarkan uji hedonik, diketahui bahwa tingkat penerimaan panelis terhadap tekstur biskuit (crackers) ikan Patin Siam (Pangasius hypophthalmus) menghasilkan rata-rata nilai tekstur biskuit (crackers) ikan Patin Siam (Pangasius hypophthalmus) berkisar antara 2,42 sampai 3,66. Tingkat kesukaan nilai tertinggi terdapat pada perlakuan C2 (10\% Tepung ikan Patin Siam) dan terendah terdapat pada perlakuan C5 (40\% Tepung ikan Patin Siam). Menurut Matz dan Matz (1978), kriteria mutu sensoris biskuit (crackers) untuk tekstur yaitu, biskuit (crackers) sebaiknya renyah lembut.

Hal ini disebabkan tekstur biskuit (crackers) ikan Patin Siam (Pangasius hypophthalmus) yang dihasilkan keras. Selain itu, panelis menyukai biskuit (crackers) yang renyah, seperti biskuit (crackers) C2 dan C3 yang menambahkan tepung ikan Patin Siam lebih sedikit dibandingkan C5 dengan penambahan tepung ikan Patin Siam yang lebih banyak dan membuat biskuit (crackers) C5 cenderung lebih keras. Hal ini disebabkan banyak mineral yang terkandung di tepung ikan Patin Siam serta pada tepung ikan Patin Siam (Pangasius hypophthalmus) tidak mengandung gluten yang merupakan komponen sangat penting dalam proses adonan yang akan mempengaruhi tekstur biskuit (Manley, 2000).

\section{Aroma}

Nilai rata - rata aroma biskuit (crackers) ikan Patin Siam (Pangasius hypophthalmus) dapat dilihat pada Gambar 13.

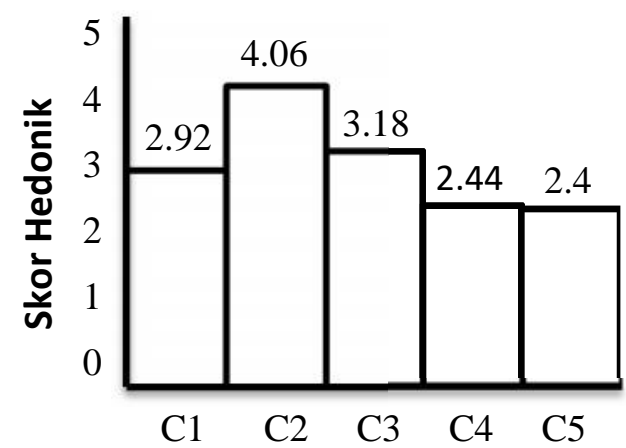

Perlakuan Tepung Ikan Patin Siam

Gambar 13. Rata-rata skala hedonik aroma biskuit (crackers) ikan Patin Siam (Pangasius hypophthalmus)

Hasil uji Friedman Conover menyatakan bahwa konsentrasi perlakuan penambahan tepung ikan Patin Siam (Pangasius hypophthalmus) yang berbeda pada biskuit (crackers) berbeda nyata terhadap aroma yang dihasilkan oleh karena itu dilakukan uji lanjut Friedman Conover. Berdasarkan uji hedonik, diketahui bahwa tingkat penerimaan panelis terhadap aroma biskuit (crackers) ikan Patin Siam (Pangasius hypophthalmus) menghasilkan rata - rata nilai aroma biskuit (crackers) ikan 
Patin Siam (Pangasius hypophthalmus) berkisar antara 2,42 sampai 4,06. Tingkat kesukaan nilai tertinggi terdapat pada perlakuan $\mathrm{C} 2(10 \%$ Tepung ikan Patin Siam) dan terendah terdapat pada perlakuan C5 (40\% Tepung ikan Patin Siam). Nilai rata-rata aroma yang dihasilkan, semakin tinggi perlakuan konsentrasi penambahan tepung ikan Patin Siam (Pangasius hypophthalmus) yang ditambahkan ke dalam formulasi biskuit, maka nilai rata-rata kesukaan terhadap aroma semakin kecil. Hal ini diduga bahwa panelis masih belum terbiasa dengan aroma ikan Patin Siam (Pangasius hypophthalmus) yang terlalu dominan ada biskuit. Menurut Winarno (1997), penambahan bahan pangan dapat mempengaruhi aroma biskuit.

\section{Rasa}

Nilai rata - rata rasa biskuit (crackers) ikan Patin Siam (Pangasius hypophthalmus) dapat dilihat pada Gambar 14.

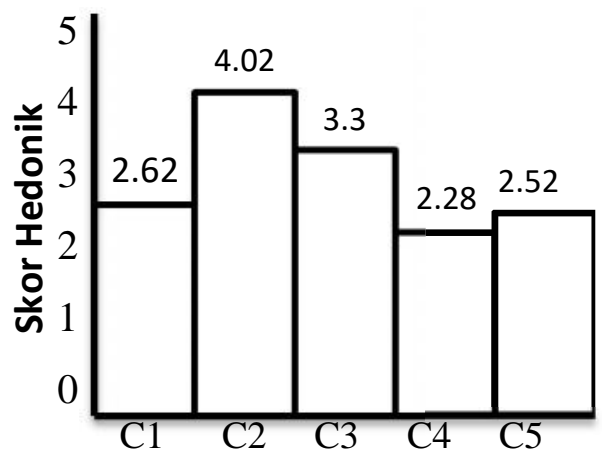

Perlakuan Tepung Ikan Patin siam

Gambar 14. Rata-rata rasa hedonik rasa biskuit (crackers) ikan Patin Siam (Pangasius hypophthalmus)

Hasil uji Friedman Conover menyatakan bahwa konsentrasi perlakuan penambahan tepung ikan Patin Siam (Pangasius hypophthalmus) yang berbeda pada biskuit (crackers) tidak berbeda nyata terhadap rasa yang dihasilkan. Oleh karena itu, tidak dilakukan uji lanjut Friedman Conover. Berdasarkan uji hedonik, diketahui bahwa tingkat penerimaan panelis terhadap rasa biskuit (crackers) ikan Patin Siam (Pangasius hypophthalmus) menghasilkan rata-rata nilai rasa biskuit (crackers) ikan Patin Siam (Pangasius hypophthalmus) berkisar antara 2.28 sampai 4,02. Tingkat kesukaan nilai tertinggi terdapat pada perlakuan C2 (10\% Tepung ikan Patin Siam) dan terendah terdapat pada perlakuan C4 (30\% Tepung ikan Patin Siam). Hal ini diduga panelis belum terbiasa dengan biskuit yang mempunyai rasa tepung ikan Patin Siam yang terlalu dominan, padahal biskuit ikan mengandung protein yang tinggi. Menurut Winarno (1997), rasa suatu bahan pangan dipengaruhi oleh beberapa faktor yaitu senyawa kimia, temperatur, dan interaksi dengan komponen rasa yang lain.

\section{KESIMPULAN DAN SARAN}

\section{Kesimpulan}

Berdasarkan hasil penelitian yang diperoleh, maka dapat disimpulkan sebagai berikut :

1. Perlakuan penambahan tepung ikan Patin Siam (Pangasius hypopthalmus) terbaik terdapat pada perlakuan C2 (10\% Tepung Ikan Patin Siam (Pangasius hypophthalmus) dengan: tekstur $262,4 \mathrm{gF}$ dan warna lightness 58,50, chroma 24,07, hue 67,97.

2. Perlakuan terbaik terdapat pada perlakuan C2 (10\% Tepung ikan Patin Siam (Pangasius hypophthalmus)), dengan kadar air 5,65\%, kadar abu 3,46\%, kadar lemak 27,75\%, kadar protein 29,37\%, kadar karbohidrat 33,94\%.

3. Perlakuan terbaik terdapat pada perlakuan C2 (10\% Tepung ikan Patin Siam (Pangasius hypophthalmus)) dengan mutu organoleptik : penampakan 3,24 , Rasa 4,02, warna 3,82, tekstur 3,66, aroma 4,06. (4) Perlakuan terbaik terdapat pada perlakuan C2 dengan konsentrasi : $10 \%$ Tepung ikan Patin Siam (Pangasius hypophthalmus).

\section{Saran}

1. Untuk mendapatkan biskuit (crackers) ikan Patin Siam (Pangasius hypophthalmus) yang disukai disarankan menggunakan C2 (610) (10\% Tepung ikan Patin Siam (Pangasius hypophthalmus)).

2. Masih perlu dilakukan penelitian lebih lanjut mengenai umur lama simpan biskuit (crackers) ikan Patin Siam (Pangasius hypophthalmus).

\section{DAFTAR PUSTAKA}

Afrianto, E dan Liviawaty E. 2011. Pengawetan dan Pengolahan Ikan. Kanisius. Yogyakarta.

AOAC. 2005. Methods of Analysis. Association of Official Agricultural Chemist. Washington DC.

Apriyanto. A. 2006. Bahan Pembuat Bakery dan Kue. http://dunia.pelajar- islam.or.id. 
Diakses Tanggal 4 April 2013. Tembilahan.

BSN. 2002. Kandungan Gizi Ikan Patin SNI 016483.5-2002. Badan Standarisasi Nasional. Jakarta.

BSN. 2006. Persyaratan Air Untuk Industri Pengolahan. 01-3553-2006. Badan Standardisasi Nasional. Jakarta.

BSN. 2009. Komposisi Kimia Tepung Terigu. Badan Standardisasi Nasional. Jakarta.

Buckle, K. A., R. A. Edwards, G. H. Fleet, dan M. Wotton. 1987. Ilmu Pangan. Diterjemahkan oleh: H. Purnomo dan Adiono. UI Press, Jakarta.

Fachruddin. 1998. Bahan Tambahan Makanan. Gramedia. Jakarta.

Faridi H. 1994. The Science of Cookie and Cracker Production. New York: Chapman $\&$ Hall.

Hadiwiyoto S. 1993. Teknologi Hasil Perikanan. Liberty. Yogyakarta.

Kaya. 2008. Pemanfaaatan Tepung Tulang Ikan Sebagai Alternatif Sumber Kalsium Dalam Kerupuk. Skripsi. Fakultas Perikanan dan Ilmu Kelautan. Institut Pertanian Bogor. Bogor. (tidak dipublikasikan).

Khairuman dan Sudenda, Dodi. 2009. Budi Daya Patin Secara Intensif Revisi. Agromedia Pustaka, Jakarta.

Manley D. 2000. Technolgy of Biscuit, Crackers, and Cookies Third Edition. CRC Press. Wahsinghton.
Rahayu, W.P. 2001. Penuntun Pratikum Penilaian Organoleptik. Jurusan Teknologi Pangan dan Gizi Fakultas Teknologi Pertanian Institut Pertanian Bogor, Bogor.

Matz S.A. \& T.D. Matz. 1998. Cookies and Crackers Technology. Connecticut: The AVI Publishing Company.

Mudjajanto, E.S. \& L. N. Yulianti. 2004. Seri Agrotekno Membuat Aneka Roti. Penerbit Swadaya, Jakarta.

Poedjiadi, A. 1994. Dasar - Dasar Biokimia. UIPress Jakarta.

Raikos, V.L., Campbell, and S.R. Evston. 2006. Effects of Sucrose and Sodium Chloride on Foaming Properties of Egg White. Conecticut: the AVI Publishing Company.

Saanin, H. 1984. Taksonomi dan Kunci Identifikasi Ikan 1 dan 2. Bina Cipta. Bandung.

Saparinto, C. dan D. Hidayati. 2006. Bahan Tambahan Pangan. Kanisius, Yogyakarta.

Sudarmaji, Slamet, Bambang Haryono, dan Suhardi. 1989. Prosedur Analisa untuk Bahan Makanan dan Pertanian. Liberty. Yogyakata.

Whiteley, P. R. 2001. Biscuit Manufacture: Fundamentals of In-Line Production. Applied Science Publishers, Ltd, London. 
Jurnal Ilmu-Ilmu Perikanan dan Budidaya Perairan Volume 13, Nomor 2, Desember 2018 
